\title{
Analisis Implementasi Quality Management System Pada Penyimpanan Peralatan Unit Pkp-Pk Di Bandar Udara Nusawiru
}

\author{
Muh. Fauzan Arifqi, Prapanca Yusuf Alqori, Savero Muharis' Wendy Firmansyah N. S, Rini \\ Sadiatmi, Oke Hendra \\ Politeknik Penerbangan Indonesia Curug \\ * e-mail: rini.sadiatmi.rs@gmail.com
}

\begin{abstract}
Abstrak
Penelitian ini bertujuan melihat implementasi Quality Management System pada Unit PKP-PK Bandar Udara Nusawiru. Metodologi kajian yang digunakan adalah kualitatif analisis. Teknik kualitatif yang digunakan yaitu teknik triangulasi antara lain, Observasi, yang dilakukan dengan mendatangi Fire Station Bandar Udara Nusawiru, Wawancara, dan Analisis. Hasil yang didapatkan ialah penerapan Quality Management System pada unit PKP-PK Bandar Udara Nusawiru belum tertata dengan baik dan belum memenuhi Quality Management System.
\end{abstract}

Kata Kunci: PKP-PK, Pemeliharaan, Peralatan, Quality Management System

(\$) Licensees may copy, distribute, display and perform the work and make derivative works and remixes based on it only if they give the author or licensor the credits (attribution) in the manner specified by these. Licensees may copy, distribute, display, and perform the work and make derivative works and remixes based on it only for non-commercial purposes.

\section{PENDAHULUAN}

Pertolongan Kecelakaan Penerbangan dan Pemadam Kebakaran (PKP-PK) memiliki fasilitas yang terdiri dari kendaraan, peralatan operasional, dan semua sarana dan prasarana pendukung dan sumberdaya manusia tersedia pada setiap bandar udara agar dapat memberikan pertolongan di saat terjadi kecelakaan penerbangan atau pemadaman kebakaran di area tersebut (KP 14, 2015), (UU No.1:2009) dan (Nugraha, Abdullah , Sutiyo, Hendra, \& Marwan, 2021). Hal ini tidak lepas dari managemen penyimpanan peralatan yang akan mempermudah dan membuat peralatan PKP-PK menjadi selalu ready for use. Pentingnya aspek keselamatan seringkali dan semestinya menjadi sebuah prioritas yang utama di dunia penerbangan (Anggraeni \& Hendra, 2020), (Kalbuana, et al., 2021) dan (Riyadi , Hendra, Sadiatmi, Nugraha, \& Amalia, 2021) sehingga dapat mengurangi kejadian kecelakaan penerbangan.

Namun faktanya masih banyak bandara yang tidak menerapkan system Quality Management System (SNI:2008) dan (SNI:2015) pada penyimpanan peralatannya. Hal tersebut selain bisa mempersulit personil PKP-PK, juga bisa membuat peralatan tersebut menjadi rusak dikarenakan kebutuhan penanganan dari setiap peralatan tersebut berbeda beda. Unit PKP-PK Bandar Udara Nusawiru merupakan unit yang ada pada bandar udara yang belum sepenuhnya menerapkan Quality Management System pada penyimpanan peralatan.

Belum teraturnya penyimpanan dengan baik mengakibatkan unit PKP-PK sulit melaksanakan maintenance, dapat memperlambat operasi PKP-PK dan juga memperpendek umur dari peralatan tersebut. Peralatan yang tidak tertata dengan baik menyebabkan pernah terjadinya kehilangan peralatan yang tentu saja dapat mengganggu kinerja unit PKP-PK dalam memberikan pelayanannya. 
Pada penelitian sebelumnya yang dilakukan oleh (Susetyadi, 2012) dan (Fauzan \& Putra, 2018) penelitian ini membahas tentang evaluasi fasilitas dan peralatan PKPPK di Bandar Udara dan juga merancang sebuah system informasi perawatan kendaraan dan peralatan pemadam kebakaran dan penelitian yang dilakukan oleh (Yusuf \& Kusumawati, 2013) penelitian ini membahas tentang bagaimana proses pemeliharaan fasilitas di Bandar Udara Adi Sucipto Yogyakarta.

Berdasarkan uraian diatas, penelitian ini digunakan untuk menjawab permasalahan yaitu: (1) apa saja kelemahan yang dimiliki Quality Management System pada penyimpanan peralatan penunjang PKP-PK di Bandar Udara Nusawiru; dan (2) bagaimana cara mengatasi kelemahan Quality Manajement System yang muncul pada penyimpanan peralatan PKP-PK di Bandar Udara Nusawiru.

Penelitian ini dibatasi pada lokasi Bandar Udara Nusawiru Pangandaran dan difokuskan untuk menjawab permasalahan tentang penerapan Quality Management System pada penyimpanan peralatan di Bandar Udara Nusawiru Pangandaran

\section{METODE PENELITIAN}

Metode penelitian yang digunakan adalah kualitatif deskriptif analitik. Metode pengumpulan data dilakukan dengan kegiatan pengamatan langsung di lapangan (Darwis, Hendra, \& Purnomo, 2020) dan (Hendra, 2020) yaitu dengan datang ke lokasi sehingga dapat mengobservasi secara langsung dan mengidentifikasi lalu menganalisa tentang cara penyimpanan peralatan di Bandar Udara Nusawiru. Selanjutnya dilakukan proses pencarian informasi dengan metode wawancara secara mendalam kepada informan (Anggraeni \& Hendra, 2020) dan (Cahyani, Hendra, Sadiatmi, Nugraha, \& Habillah, 2021) kepada personil PKP-PK Bandar Udara Nusawiru yang sedang bertugas.

Setelah mendapatkan informasi mengenai penerapan Quality Management System di Bandar Udara Nusawiru selanjutnya dilanjutkan proses analisis penerapan Quality Management System berdasarkan informasi yang didapat dari proses observasi, identifikasi, analisis dan wawancara (Kalbuana, et al., 2020), dengan begitu dapat mendapatkan hasil berupa saran dan berbentuk deskripsi.

Penulisan penelitian ini dilanjutkan dengan menganalisis data yang telah terkumpul. Ada beberapa tahap yang dilakukan yaitu: (1) Reduksi data, Kegiatan yang dilakukan adalah membandingkan data yang didapat dari observasi dan wawancara, dan dikaitkan dengan kondisi penyimpanan peralatan PKP-PK.

Data tersebut dibandingkan dengan aturan yang ada sehingga muncul data yang sesuai dengan penelitian ini. Data yang tidak sesuai dengan penelitian ini akan digunakan sebagai data cadangan.

Tahap selanjutnya yaitu (2) Penyajian data, data yang sudah direduksi selanjutnya disederhanakan yang kemudian di tampilkan pada tabel 1 dibawah ini. Tahap terakhir adalah (3) Penarikan kesimpulan, setelah data hasil reduksi terkumpul dan tersaji dalam tabel penyajian data, selanjutnya data dan informasi yang diperoleh dari proses observasi, analisis dan wawancara saat melaksanakan on the job training kemudian didapatkan garis besar permasalahan dan solusi untuk mengatasi permasalahan tersebut.

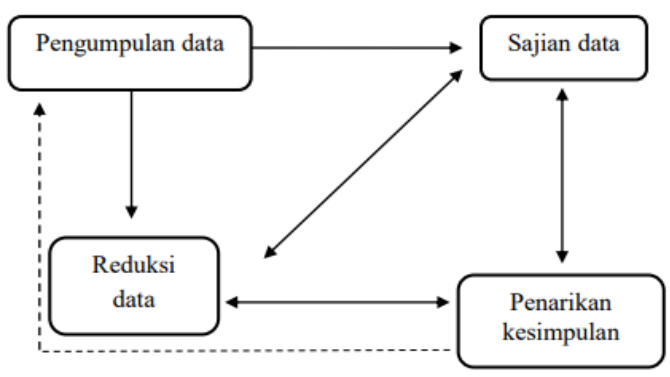

Gambar 1. Teknik Penganalisisan Data Kualitatif Miles dan Hubberman menurut Sugiyono dalam (Hendra, 2020)

\section{DISKUSI}

Sesuai dengan ketentuan pada ISO 9001: 2015 yang menyatakan bahwa sebuah organisasi semestinya dapat melakukan proses identifikasi, verifikasi, perlindungan, dan penjagaan barang milik konsumen atau milik penyedia eksternal untuk penggunaan atau penggabungan ke dalam produk dan layanan. 
Muh. Fauzan Arifqi, Prapanca Yusuf Alqori, Savero Muharis' Wendy Firmansyah N. S, Rini Sadiatmi, Oke Hendra Analisis Implementasi Quality Management System Pada Penyimpanan Peralatan Unit Pkp-Pk Di Bandar Udara Nusawiru

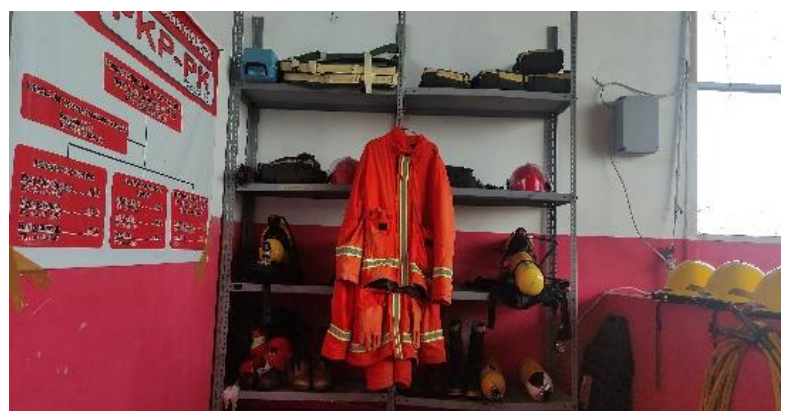

Gambar 2. Rak penyimpanan peralatan dan APD masi menyatu.

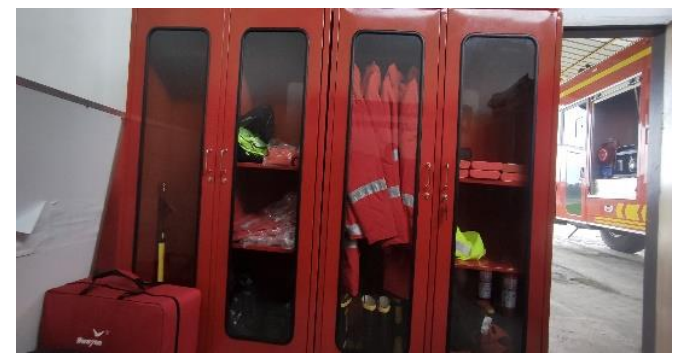

Gambar 3. Lemari penyimpanan peralatan belum cukup untuk menampung peralatan.

Barang milik pelanggan atau milik penyedia eksternal dapat meliputi bahan, komponen, peralatan dan perlengkapan, tempat, kekayaan intelektual dan data pribadi. Indikator terlaksananya QMS pada penyimpanan peralatan harus meliputi mengidentifikasi, memverifikasi, melindungi, dan menjaga. Sedangkan dari hasil observasi unit PKP-PK Bandar Udara Nusawiru indikator yang baru terlaksana yakni mengidentifikasi peralatan yang digunakan kedalam layanan PKP-PK. Sehingga dapat dikatakan unit PKP-PK di Bandar Udara Nusawiru Pangandaran masih belum sepenuhnya menerapkan Quality Management System pada penyimpanan peralatannya.

Dampak dari hal tersebut bisa menyebabkan kurang maksimalnya kinerja personil PKP-PK Bandar Udara Nusawiru Pangandaran pada saat emergency atau terjadinya crash.

Tabel 1. Informasi yang didapat dari proses penggalian informasi.

\begin{tabular}{|l|c|c|}
\hline \multicolumn{1}{|c|}{ Pertanyaan } & \multicolumn{2}{|c|}{ Kesesuaian } \\
\cline { 2 - 3 } & Ya & Tidak \\
\hline $\begin{array}{l}\text { Apakah Peralatan Utama } \\
\text { maupun pendukung operasi } \\
\text { PKP-PK di Bandar Udara } \\
\text { Nusawiru Sudah Sesuai dengan } \\
\text { yang dipersyaratkan KP 14 }\end{array}$ & & Tidak \\
Tahun 2015? & & \\
\hline $\begin{array}{l}\text { Apakah di Bandar Udara } \\
\text { Nusawiru memiliki Ruangan } \\
\text { Penyimpanan Peralatan Khusus? }\end{array}$ & Ya & \\
\hline $\begin{array}{l}\text { Apakah penempatan peralatan di } \\
\text { Bandar Udara Nusawiru sudah } \\
\text { ter-manajemen dengan baik? }\end{array}$ & & Tidak \\
\hline $\begin{array}{l}\text { Apakah di Bandar Udara } \\
\text { Nusawiru dilakukan perawatan } \\
\text { rutin terkait peralatan maupun } \\
\text { APD? }\end{array}$ & Ya \\
lancar? & & \\
\hline $\begin{array}{l}\text { Apakah di Bandar Udara } \\
\text { Nusawiru memiliki teknisi yang } \\
\text { mengerti tentang maintenance } \\
\text { paralatan PKP-PK untuk proses } \\
\text { maintenance? }\end{array}$ & Ya & \\
\hline $\begin{array}{l}\text { Apakah } \\
\text { Bandar Udara Nusensi? } \\
\text { ready for use? }\end{array}$ & & \\
\hline $\begin{array}{l}\text { Apakah personil PKP-PK di } \\
\text { Aandara Nusawiru sudah }\end{array}$ & & \\
\hline
\end{tabular}

Pada tabel 1 menjelaskan bahwa peralatan utama maupun pendukung operasi 
PKP-PK di Bandar Udara Nusawiru tidak sesuai dengan ketentuan KP 14 Tahun 2015 karena ada beberapa barang yang tidak terdapat di PKP-PK Bandar Udara Nusawiru. Kondisi tersebut dikarenakan anggaran untuk unit PKP-PK di Bandar Udara Nusawiru tidak selalu lancar, akibatnya terjadi pembagian prioritas anggaran untuk kebutuhan yang lebih mendesak. Penempatan peralatan PKP-PK di Bandar udara Nusawiru juga belum tertata dengan baik, dibuktikan pada gambar 2 yang memperlihatkan pakaian pemadam yang tergantung menumpuk dan tidak pada tempatnya. Hal tersebut menjadikan pakaian pemadam tidak bisa dikatakan ready for use karena ditempatkan tidak sesuai pada tempatnya dan dengan keadaan menumpuk sehingga dapat menyulitkan personel pada saat terjadi keadaan darurat. Permasalahan tersebut salah satunya dikarenakan personil PKP-PK Bandar Udara Nusawiru yang belum mempunyai sertifikat atau lisensi. Sehingga penerapan kompetensi untuk penyimpanan peralatan PKP-PK masih belum terlaksana.

\section{KESIMPULAN}

Berdasarkan hasil penelitian yang dilaksanakan maka didapatkan temuan bahwa Bandar Udara Nusawiru Pangandaran belum sepenuhnya menerapkan Quality Management System pada penyimpanan peralatan. Hal tersebut disebabkan oleh beberapa faktor yaitu belum adanya personil yang berlisensi dan kurangnya anggaran dari pihak UPTD (Unit Pelaksana Teknis Daerah) yang masih belum cukup untuk menerapkan Quality Management System pada penyimpanan peralatan di unit PKP-PK Bandar Udara Nusawiru Pangandaran. Selanjutnya diharapkan untuk terus melakukan pengajuan anggaran untuk memenuhi kekurangan - kekurangan yang ada. Sehingga akan adanya peningkatan Quality Management System pada penyimpanan peralatan di Unit PKP-PK Bandar Udara Nusawiru.

\section{DAFTAR PUSTAKA}

Anggraeni, D., \& Hendra, O. (2020). RANCANGAN ALAT PEMANTAU SUHU PADA RUANGAN
PERALATAN TELEKOMUNIKASI PENERBANGAN MENGGUNAKAN

LM35 BERBASIS ARDUINO UNO

DAN SIM900A. Langit Biru: Jurnal

Ilmiah Aviasi.

Cahyani, T., Hendra, O., Sadiatmi, R., Nugraha, W., \& Habillah, M. (2021).

Rancangan Monitoring Peralatan

Transmitter Very High Frequency PAE

T6T Berbasis Web Server . Journal of Airport Engineering Technology (JAET).

Darwis, Hendra, O., \& Purnomo, S. (2020).

PENYIMPANGAN PARAMETER

GLIDE SLOPE PADA PERIODISASI

KALIBRASI INSTRUMENT

LANDING SYSTEM DI BALAI

BESAR KALIBRASI FASILITAS

PENERBANGAN . Langit Biru:

Jurnal Ilmiah Aviasi .

Fauzan, M., \& Putra, B. (2018).

RANCANGAN SISTEM INFORMASI

PERAWATAN KENDARAAN DAN

PERALATAN PEMADAM

KEBAKARAN OPERASIONAL

UNIT PKP-PK PADA PT. ANGKASA

PURA II. IDEALIS.

Hendra, O. (2020). KAJIAN

PEMBELAJARAN KELOMPOK

PEMBINA TARUNA MELALUI

PENDEKATAN SYSTEM

DYNAMICS. Jurnal Sosioteknologi.

Kalbuana, N., Hendra, O., Aswia, P., Lestary,

D., Kardi, \& Solihin. (2021).

PENGENALAN UNIT

PENANGGULANGAN KEADAAN

DARURAT DI BANDARA BAGI

SISWA SMK PENERBANGAN DI

WILAYAH LAMPUNG DAN

SIDOARJO . Jubaedah : Jurnal

Pengabdian Dan Edukasi Sekolah

(Indonesian Journal of Community

Services and School Education).

Kalbuana, N., Kurnianto, B., Saputro, R.,

Hendra, O., Utami, S., \& Widagdo, R.

(2020). The Effect of Audit Quality,

Managerial ownership, Institutional

ownership, and Intellectual Capital

toward Earning Management on

Transportation Corporations in

Indonesia . Solid State Technology. 
Nugraha, W., Abdullah , A., Sutiyo, Hendra, O., \& Marwan, I. (2021). Basic PKPPK Initial Training sebagai Sarana Peningkatan Pelayanan Gawat Darurat di Bandar Udara. Darmabakti: Jurnal Inovasi Pengabdian dalam Penerbangan.

Riyadi , R., Hendra, O., Sadiatmi, R., Nugraha, W., \& Amalia, D. (2021). Potensi Bahaya pada Ujung Runway 24 Bandar Udara: Sebuah Implementasi Manajemen Resiko. Journal of Airport Engineering Technology (JAET).

Susetyadi, A. (2012). Evaluasi Fasilitas Peralatan Pertolongan Kecelakaan Penerbangan dan Pemadam Kebakaran (PKP-PK) di Bandara Haluleo Kendari. Warta Ardhia Jurnal Perhubungan Udara.

Yusuf, M., \& Kusumawati, D. (2013). Pengkajian Pemeliharaan Fasilitas PKP-PK Di Bandar Udara Adi Sucipto - Yogyakarta. Jurnal Warta Penelitian Perhubungan.

Undang-Undang Republik Indonesia Nomor 1

Tahun 2009 Penerbangan

Peraturan Direktur Jenderal Perhubungan Udara Keputusan Pemerintah Republik Indonesia nomor KP 14 tahun 2015 standar teknis dan operasi peraturan sipil bagian 135 vol iv pelayanan pertolongan kecelakaan penerbangan dan pemadam kebakaran. 26 januari 2015. Jakarta.

Standar Nasional Indonesia. 2008. Sistem Manajemen mutu - Persyaratan. ISO 9001:2008
Standar Nasional Indonesia. 2015. Sistem Manajemen mutu - Persyaratan. ISO 9001:2015 